\title{
STRUCTURAL BREAKS OR CONTINUOUS ADJUSTMENTS IN GRAIN PRODUCTION AND PRICES 1961-2014? AN EXPLORATIVE STUDY
}

\author{
Torun Fretheim
}

Norwegian University of Life Sciences, NMBU School of Economics and Business, Norway e-mail: torun.fretheim@uit.no

\begin{abstract}
This article analyses grain production and prices 1961-2014. We first describe the development in aggregated and relative allocation of land worldwide for wheat, corn and soybeans, and the growth in production volumes and yields. We then proceed by analyzing long-term price relationships. Finding that grain prices are strongly co-integrated, we estimate an Error Correction Model to see whether deviations from the long-run equilibrium are quickly adjusted. Furthermore, we investigate whether changes in land allocations for these principal field crops are best described as a continuous process or as a series of structural breaks, hypothesizing that events like the introduction of GM technologies and the "energizing" of corn after 2005 caused structural breaks in acreage shares and relative prices. Given the major and sometimes dramatic political events and technological changes during this period, one would expect to find significant structural breaks in grain production, yields and prices. However, our main conclusion is that grain markets generally adjust smoothly and continuously. Prices adjust quickly towards long-run equilibrium, and the results from a series of Chow tests indicate that the changes in relative land allocations have progressed as a relatively smooth process with few structural breaks.
\end{abstract}

Keywords: markets, Global grain production, Structural Breaks

(JEL Classification: O13, Q10, N50 )

\section{Introduction}

This article is a contribution to the understanding of longrun trends and structural changes in grain production and prices. We discuss global developments for three principal field crops, namely wheat, corn, and soybeans. Analyzing production, prices, yields, and long-term land allocation over more than half a century (1961-2014), we try to capture changes from one harvest to the next, leaving the short-term movements within the marketing year aside. Our focus is fluctuations in production (metric tons, MT hereafter), acreage (hectares, Ha hereafter), prices and yields (MT/Ha).

Empirical analyses of commodity markets often deal with relatively short horizons. A few years of monthly (or weekly or daily) observations are used as input in econometric models in order to test out hypotheses related to market behaviour and price dynamics. Such studies are, obviously, highly relevant for decision makers. Still, such short-term horizons should be supplemented with studies that cover the longer run and using observations with lower frequencies in order to capture trends and possible structural breaks. Such breaks may be identified as "a new era". As pointed out by Zulauf (2016) in his study of factors affecting long-term corn and soybean prices, economists often disagree on what constitutes a new era, see e.g. Irwin and Good $(2009,2016)$ on whether recent years can be defined as the introduction to a new era of higher agricultural prices. Using recent data on e.g. relative prices and volatility may occasionally result in near-sighted conclusions. Psychological myopia is a well-known trait in human judgements, as we often seem to believe that the recent past represents something completely new or different (see e.g. Hsee, Yu et al. (2003) for a survey).

Wheat, corn and soybeans play a central role in societies worldwide in terms of nutritional content (energy, protein). Grains also represent a major commodity in international trade. Wheat was one of the first domesticated food crops, and is a major diet component in the civilizations of Europe, West Asia and North Africa. Historically, no commercial crop has been as widely grown or heavily traded. Corn and soybeans have many uses, including human consumption, but today their primary use is as feedstock in meat production (pork, beef, chicken). 
With the introduction of the Renewable Fuel Standard (RFS) through the US Energy Policy Act of 2005, corn has also become a major input in the production of biofuels ${ }^{1}$.

Looking back, the previous decades have been characterized by globalization, dramatic political events, and significant technological innovation in the field of agriculture. Our article aims to identify whether events like wars, economic recessions, political reforms, and technological changes influence adjustments to agricultural by causing structural breaks in relative land allocations, prices and risk. Focusing on some of the events that pertain specifically to agriculture, we employ formal tests where the null is in favour of the primer, i.e. continuity. This research question is relevant in two dimensions. First, a large part of the global population relies on grains as the main part of their staple diet, which means that variations in production and prices of these commodities can come at great human cost, especially in poorer nations. Second, virtually all economies trade in food, which means that dramatic changes in grain production and prices may lead to trade bill effects of significant magnitudes.

Concerns about rising food prices and commodity price variability are widely recognized in the literature. Wright (2011) discusses the economics of grain price volatility and the importance of understanding the relationship between consumption, available supplies and stocks. Other relevant studies include Gilbert and Morgan (2010) who examine historical food price volatility; Radetzki (2006) analysing recent commodity booms, and Jacks (2013) who takes evidence on real commodity prices and discusses long-run trends, mediumrun cycles, and short-run boom/bust episodes in a very long perspective. There is also a large body of literature on whether the recent influx of index trackers and financial investors have had an adverse effect on the functioning of commodity markets. Haase, Zimmermann et al. (2016) review this literature in a recent survey, and find that the results from analyzing speculation and its impact on commodity futures markets are mixed.

The contribution of this article is a survey of the development in relative allocation of agricultural land worldwide for wheat, corn and soybeans, and the growth in production and yields since 1961. To our knowledge, we are the first to study the dynamics of land allocation, production, and yields for the major grains on a global basis. We further examine long-term price dynamics and risk, and investigate whether changes in land allocations for these principal field crops adjust continuously. Specifically, we perform a series of 1-step ahead Chow tests to see if whether major political events or technological changes manifests themselves as structural breaks in grain production. Through this approach, we seek to present empirical evidence on how producers adjust to

1 The RFS requires a minimum annual quantity of ethanol content in gasoline, and the bulk of US ethanol is produced from corn. This new source of demand has been claimed to have caused a permanent increase in world corn prices (Carter, C., et al. 2012), and thereby influenced the price and production of other agricultural commodities as producers have reallocated land to corn production and away from other crops. external events and changing consumer preferences. We also study the long-run relationship among grain prices.

The remainder of this article is organized as follows. Section 2 gives an overview of important global events which are likely to have influenced price dynamics and land allocation among the main grains, and consequently impacted global grain production. Section 3 presents the data, while section 4 gives some stylized fact on grain production and prices. In section 5, we look at long run equilibriums and short-term price adjustments in the grain markets, while section 6 tests for structural breaks in land use. Section 7 offers some concluding remarks.

\section{MATERIAL AND METHOD A historical flashback}

From 1961 through 2014, a number of important events took place in the world economy and in international trade, events that presumably had significant impacts on the production and trade in agricultural commodities. One such event was the collapse of the Bretton Woods system, which dissolved between 1968 and 1973 (IMF). Virtually all standardized contracts on agricultural commodities are priced in US dollars. While many feared that the collapse of the Bretton Woods system would destabilise the global economy, the transition to floating exchange rates turned out to be a blessing. When oil prices surged in 1973, floating exchange rates to some extent helped alleviate the impact of this external shock for many economies. The oil crisis in 1973 arose when the Arab members of the Organization of Petroleum exporting Countries (OPEC) proclaimed an oil embargo against the United States. The embargo was a response to American involvement in the 1973 Yom Kippur war, and extended to other countries that supported Israel in this conflict, including the Netherlands, Portugal, and South Africa. By the end of the embargo, global oil prices had quadrupled, and US oil prices were even higher. Energy is a major input in agricultural production through channels like farm equipment, fertilizer production and processing, packaging and transportation. One would expect changes in energy prices to have an impact on grain prices, and also on relative land allocation in global grain production. Wheat, and even more so corn, requires substantial amounts of nitrogen fertilizer in order to obtain high yields, while the soybean is a legume and can use the nitrogen in the atmosphere for plant growth. The second oil crisis of 1979, which began with a decrease in oil output due to the Iranian revolution, also resulted in widespread panic and elevated petroleum prices. An outcome of these events was a growing political willingness to reduce protectionist trade barriers like tariffs and subsidies. In particular, several countries came together on this subject through the General Agreement on Tariffs and Trade (GATT), and even though agriculture is still the most heavily protected sector in world trade, these changes in the political climate also affected agricultural trading. Given these political and economic events, one would expect to find structural breaks in global grain production and relative prices during the 1970s.

During the 80s and 90s, the global marketplace grew substantially as a number of centrally planned economies opened up towards free trade (or less protection in trade). Most notable in 
this context is the collapse of the Soviet Union, which was formally disbanded on December 26, 1991. Agricultural production in the former Soviet Union generally suffered from low productivity due to inefficient rural management, complex socially oriented problems, and cumbersome and confusing agricultural policies. These problems were obviously not solved overnight, but dramatic improvements had taken place by the end of the millennium. By 2014, the Russian Federation had become the 4th biggest exporter of wheat globally, which is reminiscent of the region's golden era prior to the First World War when Russia was the world's largest wheat producer and exporter. In 2016, Russia became the world's biggest exporter of wheat for the first time in modern history, with some 30 million MT.

Parallel to these major events in the global economy and politics there were significant developments that pertain specifically to the grains sector. New varieties and more efficient production methods contributed towards a significant increase in yields. World cereal production doubled in the time period 1960-2000 (Tilman, Cassman et al. 2002), and this growth was predominantly caused by increasing yields due to improved agronomic practices, including more optimal use of fertilizer, water and pesticides, new crop strains, and other technological advances. From 2000 onwards, there has also been rapid growth in the use of genetically modified varieties $(\mathrm{GM})^{2}$. Though controversial in some parts of the world, the use of GM technologies is widespread in corn and soybean production, and has contributed towards more efficient production of these crops. The widespread adoption of GM varieties likely comes from improved profitability over traditional methods. Other factors like producer flexibility, consumer preferences, and farmer attributes and perceptions might also influence adoption (Fernandez-Cornejo and McBride 2002). Looking to the US, GM varieties are now dominating the market for both corn and soybeans; the adoption of GM crops is approaching $100 \%$ of planted acreage, see figure 1 . As can be seen, GM varieties were introduced around the turn of the century, and their use increased rapidly. For soybeans, the relative GM share grew from about 50 to almost $90 \%$ between 2000 and 2006. Likewise, corn GM acreage grew from some $25 \%$ in 2000 to more than $80 \%$ by 2008 . One would expect to see such fundamental technological changes reflected in e.g. relative prices of corn and soybeans versus wheat, where GM technologies has yet to be introduced.

Figure 1: GM corn and soybean varieties as percentage of planted acres of the respective crops, United States, 2000-2015. Source: USDA, National agricultural Statistics Service, June Agricultural Survey for the years 2000-2015.

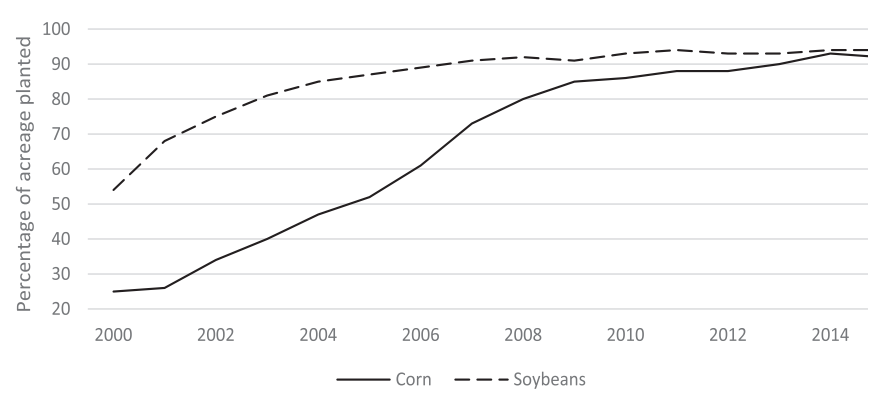

Another driving factor behind the increase in agricultural production has been expansive government policies and the cultivation of new land, in particular in Brazil. Annual soybean production increased by nearly $2000 \%$ 1968-1997, in part due to the government providing fixed nominal rate loans for equipment and operating expenses, as well as subsidising tractors and fertilizer (Frechette 1997). Furthermore, the Cerrado, a vast savannah that stretches for more than 1 000 miles across central Brazil, has been transformed from infertile land to a prosperous agricultural region by adding appropriate proportions of phosphorus and lime to the soil. Researchers developed tropical varieties of soybeans to make this crop suitable for the Amazonian region, and there has been massive agricultural expansion in Mato Grosso, which is the main production area for soybeans in Brazil. According to Arvor, Meirelles et al. (2012) the net area used for soybean production in Mato Grosso expanded by 275\% from 1992 to 2012. Soybean yields in Mato Grosso (3.08 tons per hectare) were estimated to be $17 \%$ higher than the Brazilian average (2.63 tons per hectare) in 2009. The increase in yields were largely caused by improved agricultural management practices like double cropping and no till farming, better soil and water management and more efficient use of fertilizer. This region also produces large amounts of corn, and the land allocated to corn crops expanded by a fivefold during the same period. Simultaneously, yields increased by 56 and $117 \%$ for soybeans and corn, respectively.

The turn of this century was characterized by growing demand for a number of key commodities, including agricultural products. Rapidly increasing commodity prices in 2006-08 and 2010-11 can, at least in part, be explained by this (unexpected) growth in demand in conjunction with tightening supplies. Some also suggest that monetary expansion and exchange rate movements following the financial crisis were central explanatory factors of the commodity price boom in 2007-08. A good overview of macroeconomic factors that likely contributed to the price spike in 2008, is given in (Pies, Prehn et al. 2013).

Another important development is the American political aim of promoting energy independency and environmentally friendly technologies through increased ethanol production. The US Energy Independence and Security Act of 2007 stipulated a near doubling of mandated ethanol use. Fortenbery and Park (2008) find that growth in ethanol production is important in explaining corn price determination. According to estimates by Carter, Rausser et al. (2012) the 2007 expansion in the Renewable Fuel Standard caused a 30\% increase in world corn prices. Both articles also discuss the considerable expansion in ethanol production capacity that occurred between 2005 and 2007. Abbott (2013) presents figures that document a large and persistent new demand from corn from this industry;

2 GM refers to any organism where the genetic material has been changed through genetic engineering techniques. In agriculture, the DNA of various crops is typically altered to obtain resistance to pest and diseases, to be grown in different climates, or to be resistant to certain chemical treatments (typically some herbicide). 
The amount of US corn used in ethanol production increased from $12.4 \%$ in crop year $04 / 05$ to over $38.5 \%$ in $10 / 11$. The demand from the biofuel industry has remained at this high level. Again, one would expect effects on acreage allocation and relative prices. Summarizing, global grain production has been exposed to major economic, political and technological "shocks" over the past 54 years. It appears reasonable to expect that these shocks would cause dramatic and tangible effects on production, land allocation and relative prices. On the other hand, farming has a long history of adapting rapidly to changing production conditions. The next sections of this paper will elaborate on this issue.

\section{DATA}

We focus on wheat, corn and soybeans because these commodities are chiefly grown in the same temperature zones, and thus compete for the same land resources ${ }^{3}$. Beyond being substitutes in production, they are also to some extent substitutes in consumption, in particular when used for animal feed. That corn, wheat and soybeans share a number of common factors becomes evident when we study their price history. We will illustrate and discuss how the three commodities share similar cycles and longterm trends.

Prices in this article are continuous front month futures prices from the Chicago Mercantile Exchange (CME) Group 4 . We use futures contracts because this market is forward looking by construction, quickly incorporating news and changes in expectations. Our sample covers 1961-2014. We base our analysis on annual data because prices and price expectations are dominated by the annual harvest cycle. Grain prices tend to fluctuate the most within the growing season, as supply expectations can shift significantly due to weather conditions and changes in expectations regarding harvested acreage and growing conditions. For this reason, we use prices observed in the $4^{\text {th }}$ quarter each year (the southern hemisphere has "inverse" seasons compared to the northern, and by measuring prices in December, i.e. between harvests, we average out this effect). At this point, the market should have full information about the size of the current crop year's output for corn and soybeans, and a reasonable basis for forming expectations regarding next years' market conditions based on prevailing price and storage conditions. While it is not ideal to measure wheat prices in the middle of the marketing year, we do so to obtain synchronicity across prices.

3 Rice is the staple food in the larger part of Asia, and also widely imported and consumed in the Caribbean and Central and West Africa. When we chose to exclude this commodity from our analysis, it is due to fundamental differences from the other grains. Rice is mainly consumed in different geographical regions than wheat, corn and soybeans. Furthermore, rice production requires different temperatures and different types of agricultural land to be successful, which implies that this crop does not compete with the other grains when land is allocated to food crops. We also chose not to include grains like rye, barley and oats etc., as these grains represent only a marginal part of total grain production. In 2013, global production of e.g. barley was roughly 30 million MT, or $4 \%$ of global wheat production that year.

4 All price series are downloaded through Quandl, a search engine for numerical data that offers access to a multitude of financial, economic and social datasets. See www.quandl.com for more information.
Statistics on production (MT), acreage (Ha) and yields (MT/Ha) are obtained from the Statistics Division of the Food and Agricultural Organization of the United Nations (FAOSTAT hereafter). FAOSTAT mainly collects information about agricultural output by the cooperation of governments, which supply information about primary crops through annual questionnaires (FAOSTAT). FAOSTAT also collaborate with various non-governmental agencies, to achieve conformity in the presentation of international statistics. The time reference for reporting on harvested area and crop production is based on the calendar year. More precisely, the statistics for a particular crop are reported under the calendar year in which the entire harvest or the bulk of it took place. The harvest of the crops we analyze in this paper is generally limited to a few weeks in each region. Figures are reported by the countries in various time frames like e.g. calendar year, marketing year, etc., before being allocated to the calendar year in which the entire harvest or the bulk of it took place.

\section{Stylized facts on grain prices and production 1961-2014}

Relative prices, rather than absolute prices, are the relevant input parameter in the farmer's decision process. When planning for the upcoming season, a farmer will take into account the relative prices of agricultural inputs like e.g. fertilizer, land and so on. Assuming the farmer is rational in an economic sense, she will then allocate land and other resources to the crop that yields the highest expected revenue (at similar risk levels). Because corn, wheat and soybeans to a large extent are substitutes in consumption, the relative demand for these commodities mainly depend on price. Consequently, the relative price differences between the three commodities are bound due to the consumer's ability to substitute. Short term, and sometimes violent, price variations do occur, mainly because supply is inelastic within season (a farmer cannot reap what he has not sown). However, in the longer term, the relative price differences will move back towards equilibrium. This effect is illustrated in figure 2 , which displays relative grain prices 1961-2014. As can be seen, there is no long-term (upward or downward) trend in the price ratios, and peaks do not persist (only last for a couple of years).

Figure 2: Relative front month futures prices (4 $4^{\text {th }}$ quarter) from the Chicago Mercantile Exchange Group, 1961-2014, annual observations.

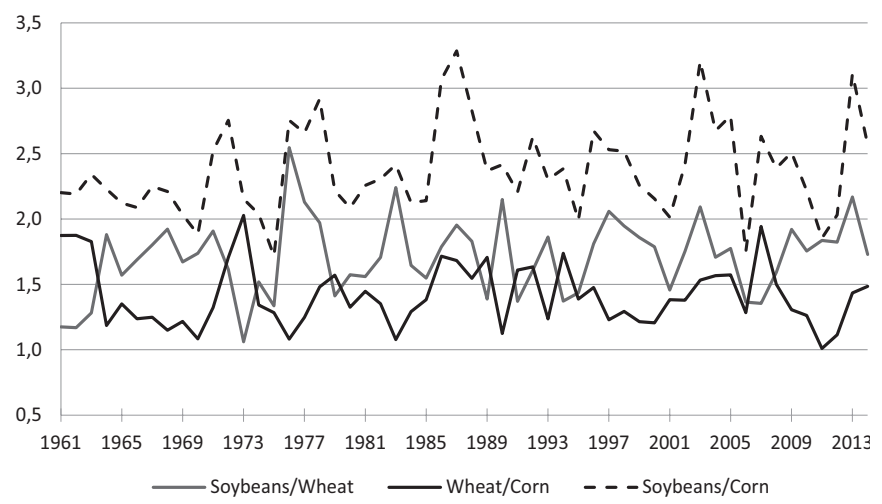


Acreage of harvested wheat, corn and soybeans increased from 334 million Ha in 1961 to 523 million Ha in 2014 (see figure 3). In other words, the total acreage allocated to produce these grains increased by roughly $50 \%$ over half a century, which corresponds to an annual trend growth of $0.7 \%$. Growth was particularly strong $1970-81$ and $1999-2014$, at a rate of $1.5 \%$ annually in each period. From 1970 to 1981, the total harvested acreage of corn, wheat and soybeans increased by 67 million Ha, i.e. an area that is roughly the total size of France. From 1999 to 2014, the increase was even larger, at some 94 million Ha.

Figure 3: Total grain area harvested (wheat, corn, soybeans) in million Ha, annual data 1961-2014. Source: FAOSTAT.

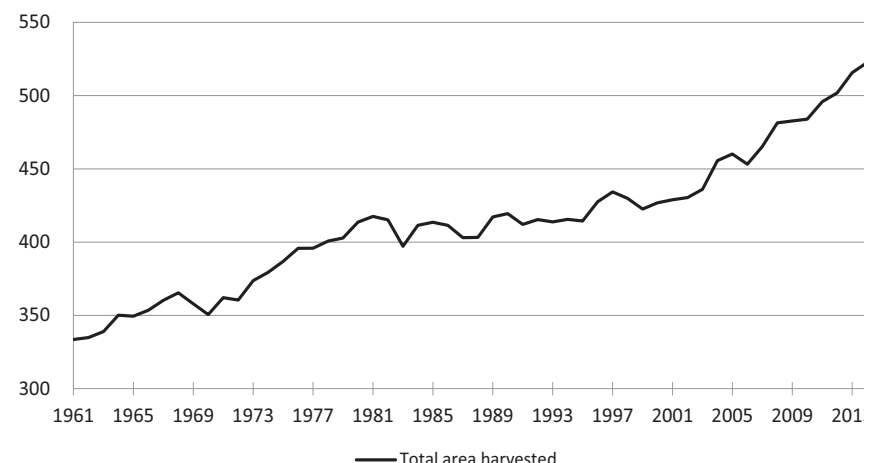

Figure 4 displays the evolution of harvested acreage for each grain individually. From 1961 to 1968 , the amount of harvested wheat acreage increased by approximately 21 million Ha, i.e. roughly $2 / 3$ of the total increase in harvested grain acreage during that period. After two years of declining acreage, growth picked up again and increased by 31 million Ha 1970-1981. This area corresponds to about half of the total agricultural land in Canada today. From 1982 onwards, there has been a downward trend in the area allocated to wheat production. This trend is reversing in 2004. The areas allocated to corn and soybean production have increased steadily throughout the last five decades. Corn area harvested has experienced a trend growth of $0.9 \%$ annually from 1970 to 2014. The growth has been even stronger for soybeans, where area harvested has increased by more than a fivefold from some 24 to 118 million Ha 1961-1970, see figure 4. This implies an annual trend growth of $2.4 \%$.

Figure 4: Harvested areas of wheat, corn, soybeans (million Ha), annual data 1970-2013. Source: FAOSTAT.

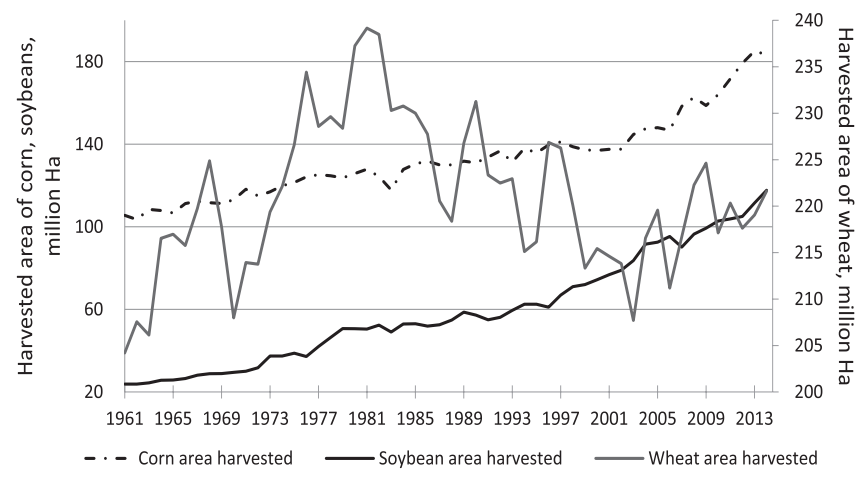

Considering the distribution of land towards production of the three main grains, wheat has been losing acreage shares. Wheat area harvested decreased from $61 \%$ of total in 1961 to $42 \%$ in 2014 . The area allocated to corn production remains relatively constant throughout the period we examine (up from 32 to $35 \%$ of total), while the acreage share of soybeans has increased dramatically from 7 to $23 \%$.

A large part of the increase in soybean acreage is located in the region of Mato Grosso, which is the main production area for soybeans in Brazil, accounting for $31.3 \%$ of national production as of 2009 (Arvor, Meirelles et al. 2012). Here, agricultural expansion has played an important part in increasing agricultural production, as previously mentioned the net area used for soybean production expanded by $275 \%$ from 1992 to 2012. Further, large areas of savannah in central Brazil have been transformed from infertile land to a rich agricultural region through new technologies.

\section{Production and yields}

Agricultural development has led to large increases in food supply feeding a growing world population. From 1961 to 2014, world population increased from some 3.000 billion people to more than 7.000 billion and a large part of this population have grains as main source of daily caloric intake. As previously mentioned, some of the growth in world grain production came about due to cultivation of new land, and more cropland has been oriented towards grain production. Nevertheless, increasing yields have been the major driving force behind the growth in grain and oilseed production from the 1960s onwards. Figure 5 shows that this increase has been largest for corn and wheat. Wheat yields have increased from 1.1 to 3.3 tons per hectare in 54 years, while corn yields are up from 1.9 to 5.6 tons per hectare. In both cases, this is equivalent to an annual trend growth of $1.9 \%$. The trend growth in soybean yields was $1.4 \%$ during the same period, and in absolute terms, soybean yields increased from 1.1 to 2.6 tons per hectare from 1961 to 2014 . Masuda and Goldsmith (2009) projects a 2.2\% annual growth in soybean production up to 2030, but also highlight a need for significant investments in yield improving research by agribusiness policy makers and managers.

Figure 5: Global grain yields; wheat, corn, soybeans (tons per hectare), annual data 1961-2014. Source: FAOSTAT.

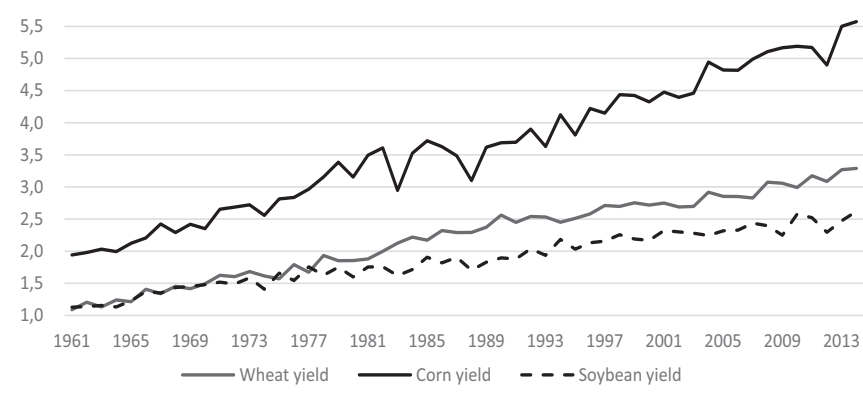

Wheat, corn and soybeans all experienced significant increase in yields at the global level from the 60 s onwards. 
However, behind the average yields reported in figure 5 there are large regional differences, and there is still room for yield growth and more efficient grain production in important agricultural regions. Large areas in Africa would benefit from better water management and modern agronomic practices, including greater inputs of fertilizer, herbicides and pesticides. Considering the African continent's climatic and soil conditions, tropical soybean varieties can be cultivated in about half of Africa's land (Kolapo 2011). This implies that the technologies employed in Brazil could possibly be imported to countries in Africa, like e.g. Mozambique or Zambia. There is also a greater potential for improved soybean yields in certain regions with the introduction of newly developed GM drought tolerant soybean strains.

Further, there are still parts of the former Soviet Union were agricultural production suffer from low productivity and inefficient agricultural management. To put this potential into context, we note that in 2012, the agricultural land in the Russian Federation, Ukraine and Kazakhstan combined amounted to approximately 465 million $\mathrm{Ha}$ (source: The World Bank). A large part of this area is allocated to wheat production, and increasing yields in this region would have a significant impact on the world supply of wheat. To illustrate the changes that have occurred in this region, we use the year 2000 as our baseline. This year, the Russian Federation exported 696 million tons of wheat, while the total exports from the Russian Federation, Ukraine and Kazakhstan combined were 4746 million tons. These are marginal magnitudes on a global basis. By 2014, the Russian Federation had become the 4th biggest exporter of wheat globally. Total exports from the Russian Federation, Ukraine and Kazakhstan combined amounted to 37.5 million tons, which made this region the biggest exporter of wheat worldwide that year (source: USDA). In 2016, Russia was expected to be (and became) the world's biggest exporter of wheat for the first time in modern history tons (Financial Times, August 18, 2016). In other words, we have seen huge efficiency gains in this region through the last decade, but there are still opportunities for improving agricultural management and technologies in the former SU.

Based on our discussion of the development in harvested acreage and yields, we know there has been a significant growth in grain production from 1961 to 2014. This growth is illustrated in figure 6 . The annual trend growth of wheat, corn and soybean production was $1.9 \%, 2.8 \%$ and $4.4 \%$, respectively. Harvested acreage of wheat actually declined during the time period we study, which implies that the increase in production came from increasing yields alone. The increase in corn production was a combination of increasing yields and harvested acreage, as were the increase in soybean production. In terms of soybeans, a large part of this increase was caused by cultivation of new land in Brazil. Looking at grains as a whole, production has increased from 450 million MT to 2059 million MT from 1961 to 2014, equivalent to a trend growth of $2.5 \%$. Annual trend growth was even higher from 2000 to 2013, at 3.0\%. For comparison, world population growth has been roughly $1.1 \%$ during the same period, which implies that grain production is now growing faster than world population.

Figure 6: Grain production, wheat, corn, soybeans, total (million tons), annual data 1961-2014. Source: FAOSTAT.

Panel a: Wheat production

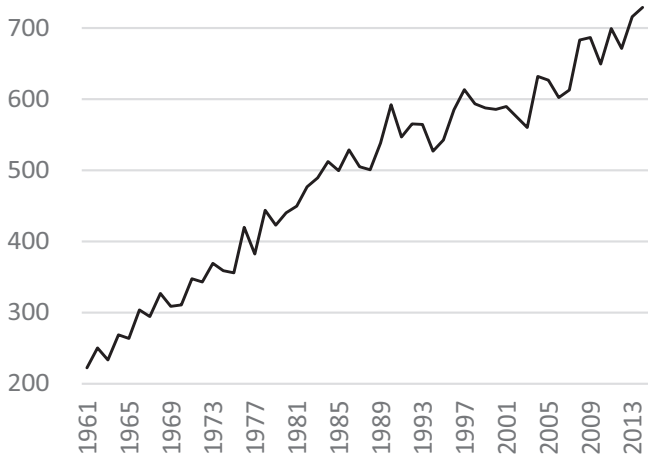

Panel c: Soybean production

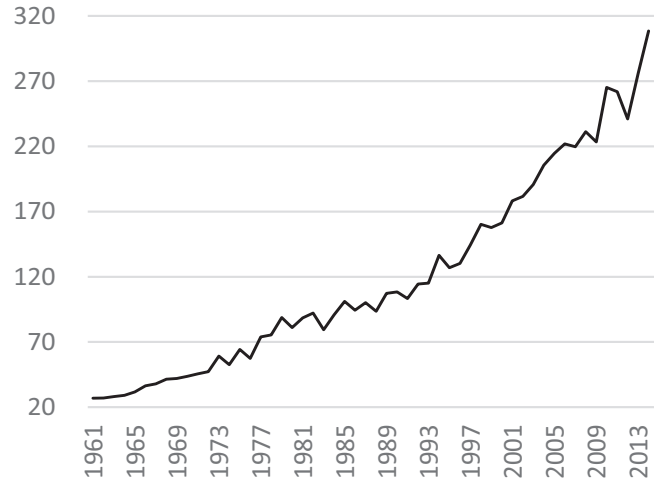

Panel b: Corn production

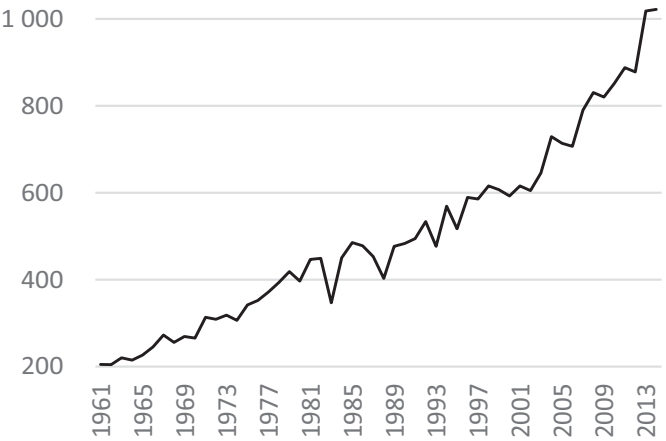

Panel d: Total grain production

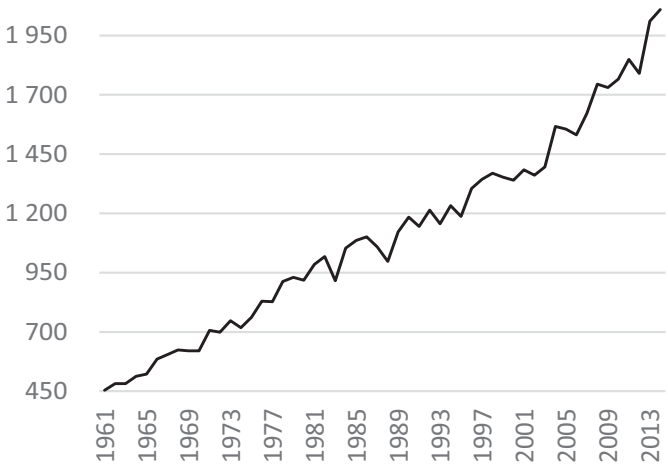




\section{PRICES AND RISK}

Despite massive increases in production and yields, concerns regarding land use and food security remain central on the international agenda. In particular, there was much talk about a global food crisis proceeding the summer of 2008 , when the prices of several important agricultural commodities had nearly doubled from the beginning of 2007. The peak in grain prices (and most other commodities) were short-lived, and in the autumn of 2008 prices fell almost as fast as they had increased just a few months earlier. However, food commodity prices rose sharply again between June 2010 and February 2011, even surpassing the record 2008 peak that had worried policymakers and non-governmental organizations across the world.

Figure 5: Global grain yields; wheat, corn, soybeans (tons per hectare), annual data 1961-2014. Source: FAOSTAT.

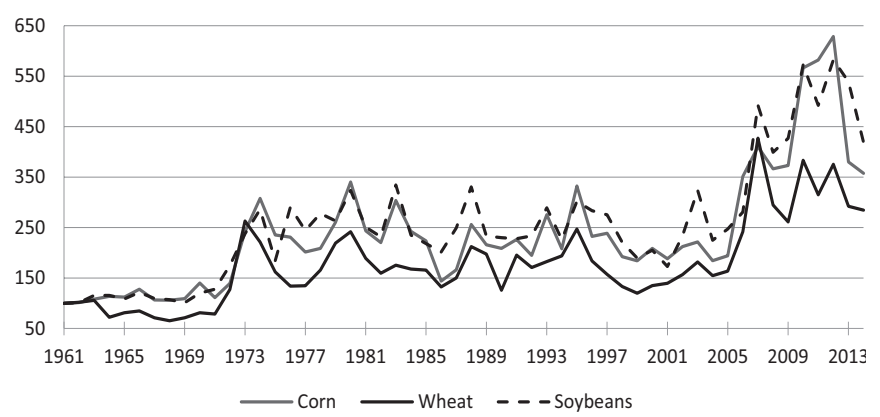

Both 2007-08 and 2010-11 were characterized by adversely affected crops in several important regions for agricultural production (Trostle, Rosen et al. 2011). Typically, agricultural price booms and periods of high volatility are caused by shocks on the supply side. In the short run, price changes are driven by inflow of information to the market place, forming expectations and speculation regarding future supply and demand dynamics. In the long run, agricultural commodity prices are determined by fundamental drivers, namely supply, demand and available inventory (Geman 2015). Factors like demographic changes and income variations influence demand, while weather patterns and adverse events like droughts or pests are key drivers on the supply side. Table 1 presents summary statistics for corn, wheat and soybeans.

Table 1: Descriptive statistics, 1961-2014, percent changes

\begin{tabular}{cccc}
\hline & Wheat & Corn & Soybean \\
\hline Average & $2 \%$ & $2 \%$ & $3 \%$ \\
St. Dev. & $24 \%$ & $24 \%$ & $22 \%$ \\
Kurtosis & 0.49 & 0.09 & -0.35 \\
Skewness & 0.61 & 0.26 & 0.08 \\
Min & $-45 \%$ & $-50 \%$ & $-40 \%$ \\
Max & $72 \%$ & $59 \%$ & $56 \%$ \\
N= & 54 & 54 & 54 \\
\hline
\end{tabular}

Annual observations, front month futures prices from the Chicago Mercantile Exchange Group, 1961-2014
The price changes of all three grain varieties are positive on average during the time period we consider. We note that as our data consist of nominal prices, the positive price changes in table 1 likely represent inflation rather than actual positive returns. The annual standard deviation of corn and wheat are identical at $24 \%$. These commodities display similar return distribution characteristics, although the statistics on wheat suggests that this distribution has slightly fatter tails compared to corn, and also moderately more positive skewness. The statistics for soybean indicates less price variability, with a standard deviation of $22 \%$ and a platykurtic distribution. To get a more dynamic impression of variability and risk, figure 8 displays the evolution in standard deviations based on a rolling window of 12 observations, 1973-2014.

Figure 8: Standard deviations for wheat, corn and soybean price changes, 12 year rolling window, 1961-2014, annual observations.

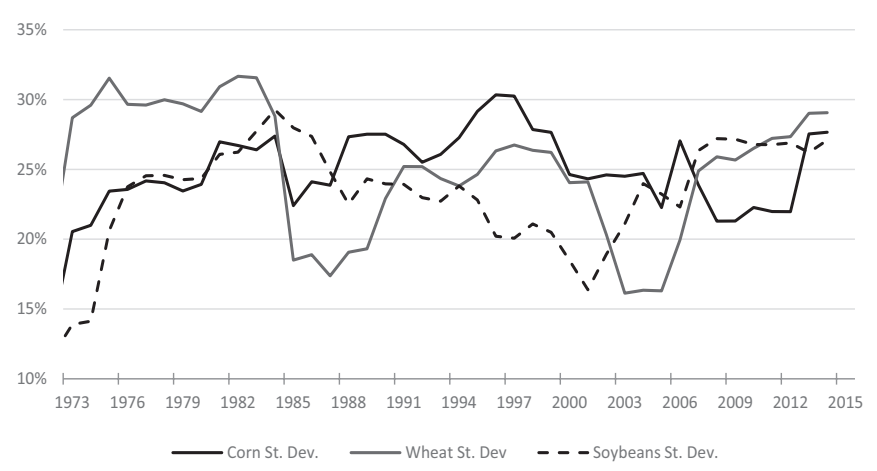

In the recent debate on food prices, many have claimed that price risk has increased significantly since 2005 (see e.g . Haile, Kalkuhl et al. (2016)). Whether or not price volatility has increased does however depend on the window we are looking through. This is demonstrated in figure 8 , where the standard deviations of the three grains based a 12-year moving window show no increasing trend in volatility. Comparing commodity risk, we see that annual volatility fluctuates within the range of $15-30 \%$ for all three grain varieties. There are individual differences in the trajectories, but the three rolling samples share common cycles. The figure shows that soybeans have lower annual volatility compared to corn and wheat.

\section{RESULTS AND DISCUSSION \\ Price Dynamics: Long-run equilibrium and short term adjustments}

Considering how grain prices share common trends and cycles, it is reasonable to expect some form of longrun relationship between the three price series. A series of Augmented Dickey-Fuller (ADF) tests reveal that grain prices observed annually 1961-2014 are non-stationary. We further find that all series are stationary when differenced once.

Following the Engle-Granger (1987) two-step procedure, we begin by performing the first step in establishing a cointegration relationship:

$p_{(i, t)}=\alpha+\beta p_{j, t}+u_{t}^{(i, j)}$ 
for all the pairs $(\mathrm{i}, \mathrm{j})$, i.e. corn-wheat, corn-soybeans and wheat-soybeans. Testing the residuals from these regressions for stationarity clearly demonstrates that grain prices are co-integrated, i.e. tied together in a long-run equilibrium (table 2).

Having found that all three grain prices are co-integrated, Table 2: Step 1 - ADF-tests for stationarity of $\hat{u}_{t}^{(i, j)}$

\begin{tabular}{ccc}
\hline & t-values & Number of lags\# \\
\hline Corn-wheat & $-5.05^{* *}$ & 0 \\
\hline Corn-soybeans & $-3.53^{*}$ & 4 \\
\hline Wheat-soybeans & $-5.27 * *$ & 2 \\
\hline
\end{tabular}

\# number of lags determined by minimizing AIC

Critical values from Engle and Yoo (1987): * 5\% = -3.29; ** $1 \%=-4.14$

we proceed by estimating Error Correction Models (ECMs). Since the OLS estimate of $\beta$ is superconsistent (Stock 1987), the sampling error from estimating it through a co-integrating equation is less important than the sampling error of the error correction model estimates asymptotically. This justifies the two-step approach, and we estimate an ECM specified as:

$$
\Delta \mathrm{p}_{(\mathrm{i}, \mathrm{t})}=\alpha+\sum_{i, j=1}^{2} \rho_{i, j}\left(p_{i, t-1}-\hat{\beta} p_{j, t-1}\right)+\varepsilon_{t}
$$

where $\Delta$ is the first-difference operator, the variable $\rho_{\mathrm{i}, \mathrm{t}}$ represents the log-price of commodity i at time t, and $\rho_{\mathrm{j}, \mathrm{t}-1}$ is the log-price of commodity $j$ at time $t-1$. The expression inside the brackets is the error correction term from the cointegration regression of $\rho_{i, t}$ on $\rho_{j, t}$. Since the two variables are cointegrated with cointegrating coefficient $\beta$, all variables in (2) are stationary. (2) describes the short-run relationship between deviations from the long-run equilibrium and changes in $\rho_{\mathrm{i}} . \rho$ is an estimate of the speed at which $\rho_{\mathrm{i}}$ returns to a long-run equilibrium after a change, or "shock". As such, the ECM recognizes that previous time periods' deviations from the equilibrium influence short-run dynamics.

Table 3: ECM model estimation results, 1961-2014

\begin{tabular}{ccccc}
\hline & $\alpha$ & $\rho_{c, s}$ & $\rho_{w, s}$ & $\rho_{c, w}$ \\
\hline \multirow{3}{*}{ Wheat } & 0.02 & & -0.62 & -0.29 \\
& $(0.59)$ & & $(-2.59)$ & $(-1.16)$ \\
& & & & \\
Corn & 0.02 & -0.33 & & -0.50 \\
& $(0.80)$ & $(-1.39)$ & & $(-2.30)$ \\
& & & & \\
Soybeans & 0.03 & 0.00 & 0.39 & \\
& $(0.90)$ & $(0.01)$ & $(1.91)$ & \\
\hline
\end{tabular}

T-Values in brackets, values significant at the $5 \%$ level is marked in bold
From table 3 we see that deviations from the longrun equilibrium between wheat and soybean prices have a significant effect on changes in wheat prices the subsequent period. The coefficient representing speed of adjustment implies that $62 \%$ of the short-run disturbance is corrected the following year. Similarly, the price of corn is "pulled back" towards the long-run equilibrium after a shock in the price of wheat. Once more, the correction is relatively swift; the estimated coefficient suggests half of the disturbance is corrected the subsequent period. The error correction mechanism between soybean prices and the other grains are not as distinct, but we see that the coefficient representing the relationship between wheat and soybeans is significant at the $10 \%$ level. The speed of adjustment is $39 \%$. As regards the topic of this article, namely whether grain prices adjust continuously, these results support the notion of prices that move rapidly back into equilibrium after an initial disturbance or shock.

\section{Testing for structural breaks in land use}

There are several studies on the acreage effects from agriculture price changes. These at least date back to the classic articles by Mark Nerlove, e.g Nerlove (1956), and a number of studies in the 1970s (e.g. Houck and Ryan (1972)). In their recent study, Haile, Kalkuhl et al. (2016) find significant and positive price elasticities on acreage using a panel data approach.

Taking a time series approach, we examine whether relative prices have a significant effect on land allocation among the main grains. Performing regressions with harvested acreage (Ha) as dependent variable we study changes in acreage caused by changes in grain prices, adjusted for area growth.

$$
d l H a_{j, t}=\alpha_{0}+\alpha_{1} d l H a_{j, t-1}+\sum_{i=1}^{3} \beta_{i} d l p_{i, t-1}+\varepsilon_{t}
$$

where the variable $\mathrm{dlHa}$ represents the logged difference of harvested acreage, the superscript $j$ indicates commodity, and the variable $\rho_{j, t-1}$ is the logged difference of the price of commodity i at time $t-1$. The lagged value of $d l \mathrm{Ha}$ controls for short-term adjustments in acreage.

Using logged difference variables on both sides of the econometric specification is convenient because all variables are now stationary, and it allows for a straightforward interpretation of the regression coefficients. All parameter estimates have a natural interpretation as percentage changes, and information about the effect of relative price differences is given by the quotient rule which states that $\ln x-\ln y=\ln (\mathrm{x} / \mathrm{y})$. We expect $\beta \neq 0$, i.e. that changes in prices lead to shortterm (annual) adjustments in harvested acreage. Table 4 presents the results. 
Table 4: the relationship between harvested acreage and last years' prices, 1961-2014

\begin{tabular}{ccccccc}
\hline & $\alpha_{0}$ & $\alpha_{1}$ & $\beta_{w}$ & $\beta_{c}$ & $\beta_{s}$ & $R^{2}$ \\
\hline \multirow{2}{*}{ Wheat } & 0.00 & 0.10 & 0.04 & 0.02 & -0.02 & $15 \%$ \\
& $(0.18)$ & $(0.68)$ & $(1.84)$ & $(0.80)$ & $(-0.97)$ & \\
\hline \multirow{3}{*}{ Corn } & 0.01 & -0.01 & 0.00 & 0.07 & -0.00 & $37 \%$ \\
& $(2.74)$ & $(-0.09)$ & $(0.23)$ & $(2.91)$ & $(-0.13)$ & \\
\hline \multirow{2}{*}{ Soybeans } & 0.02 & 0.27 & 0.02 & -0.14 & 0.20 & $42 \%$ \\
& $(3.28)$ & $(2.22)$ & $(0.57)$ & $(-4.61)$ & $(6.01)$ & \\
\hline
\end{tabular}

T-values in brackets, values significant at the $5 \%$ level is marked in bold $w=$ wheat, $c=$ corn, $s=$ soybeans

Table 4 shows that a substantial part of the variation in harvested acreage of wheat, corn and soybeans, respectively, is explained by a combination of last year's harvested acreage and relative prices. From (3) we expect high R-squared values, as farmers are likely to carry their planting patterns over from one year to the next.

Our results indicates that last year's prices of corn and soybeans have no significant effect on harvested acreage of wheat. Wheat acreage is however sensitive to changes in wheat prices (statistically significant at the $10 \%$ level), and tend to increase with $4 \%$ in response to a $1 \%$ increase in last years' wheat prices. Moving the discussion to harvested corn acreage we find similar results, harvested acreage of corn respond to last years' price of corn, and also last years' harvested corn acreage. Statistically, corn acreage increases with $0.07 \%$ in response to a $1 \%$ increase in the price of corn the previous year. Soybeans are the only field crop where we find a statistically significant relationship between harvested acreage and last years' prices of another grain variety. Harvested soybean acreage tend to decrease with $0.14 \%$ in response to a $1 \%$ increase in the price of corn the previous year. Acreage is also sensitive to changes in last years' prices, increasing by $0.20 \%$ in response to a $1 \%$ increase in lagged soybean prices. Using the quotient rule, this implies that the response towards a change in the ratio of corn vs soybean prices is -0.34, i.e. that a $1 \%$ increase in last year's price of corn relative to the price of soybeans leads to a $0.34 \%$ decrease in harvested soybean acreage.

Overall, these results are not surprising; one expects to find the closest lead-lag relationship between corn and soybeans. These commodities are to some extent substitutes in both consumption and production, they share a similar 5 -month growth cycle and require similar climatic conditions. Using the US as an example, the bulk of corn and soybeans are produced in the Midwest region, where planting starts in the beginning of April and last through June. The main harvest begins in September and is finished by the end of November at the latest. The largest exporters of corn and soybeans globally are the US, Brazil and Argentina. From 2000 onwards, Ukraine has also become a major exporter of corn, increasing their exports from some $400000 \mathrm{MT}$ in 2000, to 15500000 MT in 2015.

While it is relatively easy to switch between planting corn or soybeans, wheat stands out with its own unique growth cycle and harvest time frames. In the US, winter wheat is planted from mid-August through October, and the harvest run from mid-May to July. Further, wheat is a sturdier crop compared with corn and soybeans, and can be grown commercially in harsher climates. It follows that wheat production benefits from taking place in a number of regions, and the largest exporters of wheat are the European Union, the Russian Federation, the US, Canada, Australia and Ukraine. Kazakhstan and Argentina are also noteworthy wheat exporters.

To examine whether there have been structural breaks in the relationship between harvested acreage and last year's grain prices, we run Recursive Least Squares ( $R L S$ ) estimations with specifications as outlined above. Recursive estimations start with a minimal number of observations, and statistics are recalculated adding one new observation at a time. The coefficients of the regression are thus estimated sequentially, and studying these estimates provides information about parameter consistency and structural breaks. We employ the classical test for structural breaks, namely the 1-step-ahead Chow test, which uses an F-test to determine whether a single regression is more efficient than two separate regressions splitting the data into two sub-samples (Chow 1960). Formally, the 1-step-ahead Chow test statistic follows an F-distribution with $F(1, t-k-1)$ under the null of constant parameters, for $t=M, \ldots, T$. The test statistic is calculated by comparing the residual sum of squares across sub-periods:

$$
\frac{\left(R S S_{t}-R S S_{t-1}\right)(t-k-1)}{R S S_{t-1}}=\frac{v_{t}^{2} / w_{t}}{\hat{\sigma}_{t-1}^{2}}
$$

where RSS represents Residual Sum of Squares for each $t$, $t$ denotes sample size, $k$ is the number of parameters, and $v$ and $w_{t}$ represents the standardized innovations (standardized recursive residuals). Normality is required for the statistic to be F-distributed.

Table 5: 1-step-ahead Chow tests, 1961-2014

\begin{tabular}{cccc}
\hline & Years & df & F-values \\
& 1976 & 1,8 & 6.70 \\
Wheat & 2004 & 1,36 & 4.82 \\
\hline \multirow{2}{*}{ Corn } & 1983 & 1,15 & 10.82 \\
& & & \\
\hline \multirow{2}{*}{ Soybeans } & 1974 & 1,6 & 15.64 \\
& 1978 & 1,10 & 6.92 \\
& 1983 & 1,15 & 7.94 \\
\hline
\end{tabular}

T-values in brackets, values significant at the 5\% level is marked in bold $w=$ wheat, $c=$ corn, $s=$ soybeans 
Table 5 presents the outcome of a series of 1-step-ahead Chow test performed on the model outlined in (3). Regressing the logged difference of harvested wheat acreage on changes in relative grain prices, adjusting for short-term area adjustments we find support for the hypothesis of a structural break in 1976 and 2004. Even though these years are statistically significant, it is hard to think of historical events that might have caused these instabilities. Both years were characterized by moderate price levels, stocks were however much lower in 04 compared to 76 . Referring back to figure 4 , we believe that these breaks merely represents the beginning and end to a downward trend in the land allocated to wheat production, rather than changes of a structural character.

The 1-step Chow test on corn acreage identifies a structural break in 1983. While it is hard to identify the exact cause of this break, some reasonable conjectures can be made. In the US, it is common to speak of 1973-80 as an agricultural boom period, while the 80s was a bust decade with poor performance and low farm income. This view is supported by a $35 \%$ increase in US farm export volume from 1973-1980, an increase that was sustained by production shortfalls in other countries, a fall in the dollar's real exchange value after the collapse of the Bretton Woods system, rapid growth in foreign real income and strong support from domestic commodity programs (Belongia 1986). By the beginning of the $80 \mathrm{~s}$, farm fundamentals such as real income and relative prices were generally bearish - and even though farm productivity was increasing farmers continued to leave the sector. Turning to the Federal Reserve Bank of St. Louis' February forecasts for agriculture, 1983 was expected to be the fourth consecutive year of low farm income in the US (Belongia 1983). A record harvest in 1981, declining exports, and large carryover stocks had all contributed to depressed grain prices. Ideal weather conditions and record yields in 1982 did nothing to alleviate the situation, and the US at now held about $76 \%$ of global corn stocks and 39\% of world wheat stocks (Belongia 1983). Policy actions had been taken to encourage wheat and corn producers to reduce their planted acreage and thus reduce grain output ${ }^{6}$, but with little success - at least in terms of supporting grain prices. What ultimately made grain prices recover in 1983 was a drought induced production shortfall, when intense heat affected crops across numerous states in the Midwest and the Great Plains. This yield related disturbance had major effect on grain prices, especially for corn and soybeans. That we find no evidence of this shift in wheat prices lends support to this supposition, as wheat benefits from being produced in a number of regions, while the world relied heavily on US corn and soybean exports during the 80 s. We believe that the political incentives towards reducing grain acreage in the US and the drought induced price spike were important contributors towards the structural instability detected in 1983.

6 The 1981 US Farm Bill encouraged grain farmers to participate in a new acreage reduction program by offering deficiciency payments and price support loans in return for ideling a cropspecific percentage of their base acreage. This was an essential alteration from the former set-aside program; prior to 1981 acreage reductions were based upon current year plantings, and most importantly, the reductions were not crop-specific.
Moving to soybeans in figure 11, we find indications of structural breaks in 1974, 1978 and 1983. We are not able to identify an obvious cause for the breaks in 74 and 78 , but the evidence of a structural break in 83 lends further support to our conjecture that instability was caused by US agricultural policies and adverse conditions in the US Corn Belt.

\section{CONCLUDING REMARKS}

In this article, we have described grain acreage, yields and aggregate production, as well as price relationships for wheat, corn and soybeans in an historical setting 19612016. During this period, agriculture has been exposed to a number of dramatic changes related to input prices, agricultural technology, geopolitical events and rapid changes in consumers' income and preferences. Oil price shocks, the collapse of the Soviet Union, the introduction of GMtechnology and new demand for corn as input for biofuels are examples of events that have added to the uncertainties normally faced by farmers. One would expect such dramatic events to be reflected in grain production and prices as erratic changes or structural breaks. However, the analysis of acreage allocation, prices, production and yields tells a story of gradual adjustments and continuity - with some exceptions. Grain farmers seem to have been able to adjust successfully to both positive and adverse external events. Production, yields and grain acreage have grown at a steady rate, and the changes in land allocation towards the different crops have been relatively smooth. Likewise, price risk as measured by standard deviations have been fairly stable over the long-run, as have fluctuations in relative prices.

Considering how wheat, corn and soybeans are substitutes in production, and to some extent substitutes in consumption, it is reasonable to expect a long-run relationship between grain prices. This link is confirmed through a co-integration analysis. Estimates from ECMs shows that grain prices are cointegrated, with rapid adjustments of deviations from the long-run equilibrium. In sum, we find that despite massive international events like wars, technological changes, and so on, adjustments in agriculture are continuous and relatively smooth. Some of this continuity should be attributed to global markets that allow producers and consumers to share risk, information, and forming expectations.

\section{ACKNOWLEDGEMENTS}

I would like to thank Professor Ole Gjølberg and Associate Professor Marie Steen for their helpful comments on this paper. All remaining errors are my own.

\section{REFERENCES}

Abbott, P. (2013). Biofuels, binding constraints and agricultural commodity price volatility, National Bureau of Economic Research.

Arvor, D., M. Meirelles, V. Dubreuil, A. Begue and Y. E. Shimabukuro (2012). "Analyzing the agricultural transition in 
Mato Grosso, Brazil, using satellite-derived indices." Applied Geography 32(2): 702-713.

Belongia, M. T. (1983). Outlook for Agriculture in 1983. Unite States, The Federal Reserve Bank of St. Louis. 65: 14-23.

Belongia, M. T. (1986). The farm sector in the 1980s: sudden collapse or steady downturn. United States, The Federal Reserve Bank of St. Louis. 68: 17-25.

Carter, C., G. Rausser and A. Smith (2012). "The effect of the US ethanol mandate on corn prices." Unpublished manuscript.

Chow, G. C. (1960). "Tests of equality between sets of coefficients in two linear regressions." Econometrica: Journal of the Econometric Society: 591-605.

Engle, R. F. and C. W. Granger (1987). "Co-integration and error correction: representation, estimation, and testing." Econometrica: journal of the Econometric Society: 251-276.

Engle, R. F. and B. S. Yoo (1987). "Forecasting and testing in co-integrated systems." Journal of econometrics 35(1): 143-159.

FAOSTAT (2016). "Methodology." http://faostat3.fao.org/mes/ methodology_list/E Retrieved 12.12.2015.

Fernandez-Cornejo, J. and W. D. McBride (2002). Adoption of bioengineered crops. Agricultural Economic Report No. 810, U.S. Department of Agriculture.

Fortenbery, T. R. and H. Park (2008). The effect of ethanol production on the US national corn price, University of Wisconsin, Agricultural and Applied Economics.

Frechette, D. L. (1997). "The dynamics of convenience and the Brazilian soybean boom." American Journal of Agricultural Economics 79(4): 1108-1118.

Geman, H. (2015). Agricultural finance: from crops to land, water and infrastructure. United Kingdom, John Wiley \& Sons.

Gilbert, C. L. and C. W. Morgan (2010). "Food price volatility." Philosophical Transactions of the Royal Society B: Biological Sciences 365(1554): 3023-3034.

Haase, M., Y. S. Zimmermann and H. Zimmermann (2016).

"The impact of speculation on commodity futures markets-A review of the findings of 100 empirical studies." Journal of Commodity Markets 3(1): 1-15.

Haile, M. G., M. Kalkuhl and J. von Braun (2016). Worldwide acreage and yield response to international price change and volatility: a dynamic panel data analysis for wheat, rice, corn, and soybeans. Food Price Volatility and Its Implications for Food Security and Policy, Springer: 139-165.

Houck, J. P. and M. E. Ryan (1972). "Supply analysis for corn in the United States: the impact of changing government programs." American Journal of Agricultural Economics 54(2): 184-191.

Hsee, C. K., F. Yu, J. Zhang and Y. Zhang (2003). "Medium maximization." Journal of Consumer Research 30(1): 1-14.

IMF "The end of the Bretton Woods System (1972-81)." https:// www.imf.org/external/about/histend.htm. Retrieved 12.12.2015. Irwin, S. and D. Good (2016). "The New Era of Corn and Soybean Prices Is Still Alive and Kicking." farmdoc daily (6): 78."

Department of Agricultural and Consumer Economics, University of Illinois at Urbana-Champaign.

Irwin, S. H. and D. L. Good (2009). "Market instability in a new era of corn, soybean, and wheat prices." Choices 24(1): 6-11.

Jacks, D. S. (2013). From boom to bust: A typology of real commodity prices in the long run, National Bureau of Economic Research.

Kolapo, A. (2011). Soybean: Africa's Potential Cinderella Food Crop. Soybean - Biochemistry, Chemistry and Physiology. T.-B. Ng. Available from: http://www.intechopen.com/books/soybeanbiochemistry-chemistry-and-physiology/soybean-africa-s-potential-cinderella-food-crop. Retrieved 12.06.2016.
Masuda, T. and P. D. Goldsmith (2009). "World Soybean Demand: An Elasticity Analysis and Long-Term Projections " National Soybean Research Laboratory, University of Illinois at Urbana-Champaign Available from: http://ageconsearch.umn.edu/ bitstream/49490/2/MasudaGoldsmith 609089AAEA20090501. pdf. Retrieved 02.06.2017.

Nerlove, M. (1956). "Estimates of the elasticities of supply of selected agricultural commodities." Journal of Farm Economics 38(2): 496-509.

Pies, I., S. Prehn, T. Glauben and M. G. Will (2013). "Speculation on Agricultural Commodities: A Brief Overview." Available at SSRN 2333087.

Radetzki, M. (2006). "The anatomy of three commodity booms." Resources Policy 31(1): 56-64.

Stock, J. H. (1987). "Asymptotic Properties of Least Squares Estimators of Cointegrating Vectors." Econometrica 55(5): 10351056.

Terazono, E. (2016). Russia set to be biggest wheat exporter for first time. Financial Times. https://www.ft.com/content/af66f51e6515-11e6-8310-ecf0bddad227. Retrieved 12.03.2017.

Tilman, D., K. G. Cassman, P. A. Matson, R. Naylor and S. Polasky (2002). "Agricultural sustainability and intensive production practices." Nature 418(6898): 671-677.

Trostle, R., S. Rosen and P. Westcott (2011) "Why Have Food Commodity Prices Risen Again?".

Wright, B. D. (2011). "The Economics of Grain Price Volatility." Applied Economic Perspectives and Policy 33(1): 32-58.

Zulauf, C. (2016). "Examining Factors Affecting Long Term Corn and Soybean Prices." Farmdoc Daily: http://farmdocdaily. illinois.edu/2016/2003/factors-affecting-long-term-corn-soybeanprices.html. Retrieved 2020.2012.2016. 


\title{
URBAN FOOD CROP FARMING AND FARM HOUSEHOLDS' FOOD SECURITY STATUS IN OYO STATE, NIGERIA
}

\author{
David Tobi Olaleye ${ }^{1}$, Abiodun Elijah Obayelu² and Omotoso Oluseye Ogunmola ${ }^{3}$
}

\begin{abstract}
${ }^{1}$ Federal University of Agriculture, Abeokuta, Nigeria, Department of Agricultural Economics and Farm Management, PMB 2240, Abeokuta Ogun State, Nigeria1 olaleyedavidtobi@gmail.com

${ }^{2}$ Federal University of Agriculture, Abeokuta, Nigeria, Department of Agricultural Economics and Farm Management, PMB 2240, Abeokuta Ogun State, Nigeria2 obayelu@yahoo.com
\end{abstract}

${ }^{3}$ Federal University of Agriculture, Abeokuta, Nigeria, Department of Agricultural Economics and Farm Management, PMB 2240, Abeokuta Ogun State, Nigeria3 vicsteve99@gmail.com

\begin{abstract}
Food production and supply has been on the decline in Nigeria with a consequent impact on household food security. This study examined the influence of urban farming on household food security in Oyo State, Nigeria. Multi-stage sampling procedure was used to select 159 farm households in a cross-sectional survey. Structured questionnaire was used to obtain data on socio-economic characteristics, determine the food security status of urban crop farming households in the study area, and examine the effects of urban crop production on households' food security status. Data were analysed using descriptive statistics while the statistical tools were Food Security Index (FSI) and Probit Regression Model $(P R M)$. Results revealed that $84.9 \%$ of the respondents was male, $81.2 \%$ married. The average age, household size, and farm size were 49.6 years, 6 persons, 1.1 hectares respectively. Most (75.5\%) of the respondents did not have access to consumption credit and $62.3 \%$ did not belong to any farmers association. Based on minimum daily energy requirement per adult equivalent of N230.8, 90.6\% of the farm households was food secure. The PRM showed that age $(\beta=-0.1, p<0.05)$, household size $(\beta=-0.4, p<0.01)$ and economic efficiency $(\beta=-61.6, p<0.05)$ reduced the probability of household food security while access to consumption credit $(\beta=1.7, p<0.05)$ and allocative efficiency $(\beta=67.9, p<0.05)$ increased the probability of household food security. The study concluded that urban farming significantly influence household food security.
\end{abstract}

\section{Keywords: Food Security, Urban Food Crop, Food Security Index, Probit Regression Model} (JEL Classification: $Q 11$ )

\section{Introduction}

Urban agriculture practice is a major strategy towards improving food security in many cities throughout the world (Chaminuka and Dube, 2017). The challenge of feeding cities lies in enhancing consumer access to food by ensuring increased local food production, processing and distribution as well as reversing dependence on distant production sites, thus enabling cities to become more autonomous in food production (JONGWE, 2014).Urban food insecurity is a growing challenge emanating from rapid urbanization and rising poverty. Urbanization increases resource competition, costs of supplying, distributing and accessing food, thus negatively impacting on urban household food security (Rabinowicz, 2002).

Among the developmental problems Nigeria is faced with, food insecurity ranks topmost (Babatunde et al., 2007a). The level of food insecurity has continued to rise steadily since the early 1980s. It rose from $18 \%$ in 1986 to about $41 \%$ in 2004 (SANUSI et al., 2006).A large proportion of urban households and dwellers in Nigeria merely eat for survival despite their involvement in urban agriculture, just like many rural households whose occupation is predominantly agriculture (Obayelu, 2012). This implies the existence of some disjoint relationship between household food security and urban food production. This study sought to provide answers to the irregular relationship by the following research questions: $i$. What are the socio-economic characteristics of the urban farming households in the study area? ii. What is the food security status of urban farming households in the study area? iii. What are the effects of urban food crop production on households' food security status?

Food security can be elaborated into four dimensions which are: food availability, food accessibility, food utilization and stability of food supply (Jrad et al. 2010). Food availability has to do with physical presence of food which may come from own production, purchases from internal market or import from overseas for consumption (Gregory et al. 2005). Household food access deals with the ability to obtain sufficient food of guaranteed quality and quantity to meet nutritional requirements 
of all household members. Food utilization entails ingestion and digestion of adequate and quality food for maintenance of good health (Jrad et al., 2010). Stability of food supply is achieved when there is a continuous supply of adequate food all year round without shortages (Jrad et al., 2010).

Figure 1: Conceptual Framework Showing Relationship between Urban Agriculture and Food Security (2017)

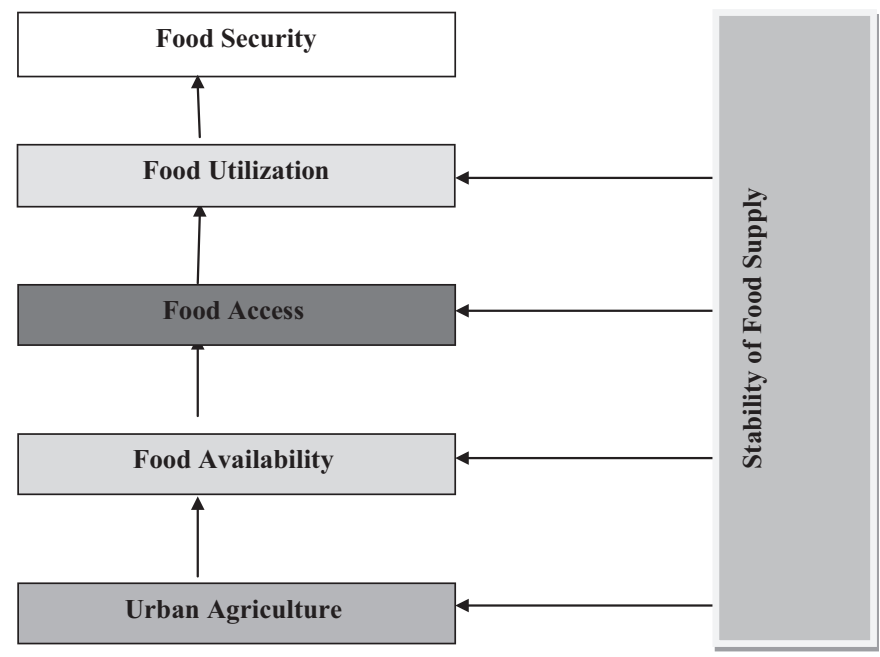

\section{MATERIAL AND METHOD Study Area}

Oyo State covers an area of 28,454 square kilometres and has a population of 5,591,589 people according to the 2006 population census. It lies between latitudes 7o 31N and 9o121N and longitudes 2o 471E and 4o 231E (NPC, 2006). Oyo State has the largest arable urban farmland among other South-Western states in Nigeria with about 27,107.5 square kilometres which can be used to cultivate food crops like: cereals (rice, maize and guinea corn), legumes (cowpea, and soybeans), root and tuber (sweet potato, cassava and yam) (Goudie, 2002).

\section{Sampling Procedure and Sample Size}

Multistage sampling procedure was employed in the selection of 159 households from the study area. Oyo State is divided into four agricultural zones which are: Saki/Okeogun, Ibadan/Ibarapa, Oyo, and Ogbomoso zones. In the first stage, all the four agricultural zones of the state were used for proper representation of urban food crop farmers in the study area. The second stage was a purposive selection of blocks in each zone where urban food crop farmers were identified.

\section{Estimation of food security status of urban crop farming households}

The cost of calorie (COC) intake proposed by Foster, Greer and Thorbecke, (1986) was adopted to determine a threshold food security line. This method has been applied to several studies with main focus on food security (Asogwa and Umeh, 2012; Olagunju et al., 2012; Ahmed And Abah, 2014). The COC yields a threshold value which is close to the minimum calorie requirement for human survival. Following the approach of earlier studies, the food insecurity line is given as:

$$
\ln \mathrm{h}=\mathrm{a}+\mathrm{bC}
$$

Where $\mathrm{h}=$ daily adult equivalent food expenditure in naira $\mathrm{C}=$ actual calorie consumption per adult equivalent in a household (kcal)

$\mathrm{a}=$ model intercept

$\mathrm{b}=$ model slope

FAO's recommended minimum daily calorie requirement per adult equivalent is $2260 \mathrm{kcal}$; this was used to determine the food insecurity line using the equation:

$$
\mathrm{Z}=\mathrm{e}^{(\mathrm{a}+\mathrm{bL})}
$$

Where $\mathrm{Z}=$ food security status

$\mathrm{L}=$ recommended minimum daily calorie intake level per adult equivalent of $2260 \mathrm{Kcal}$.The daily calorie consumption was estimated using the calorie content conversion factor (Table 4) of the consumed food item in each household as used by Babatunde et al., (2007b) and Ayantoye et al., (2011). The daily household calorie intake was then divided by the adult equivalent conversion factor (Table 5) to obtain the daily calorie intake per adult equivalent as used by Babatunde et al., (2007b).

\section{Effects of urban crop production on households' food security status}

The probit regression model was used to analyze the effect of urban food crops farming on households' food security status of urban farm households. The food security status of households which is bivariate, taking the value of 1 for food secure households and 0 for food insecure households was used as the dependent variable. The choice of probit model is because it assumes there is a latent, unobserved continuous variable $Z^{*}$ that determines the value of $\mathrm{Z}$ and includes observable error term distribution as well as realistic probabilities (Adepoju and Adejare, 2013; Yusuf et al., 2015).

$\log \frac{P i}{1-P i}=Z_{i}=\alpha+\beta_{i} \mathrm{~W}_{i}$

$\mathrm{Z}_{i}=\alpha+\beta_{1} \mathrm{~W}_{1}+\beta_{2} \mathrm{~W}_{2}+\ldots \ldots \ldots+\beta_{n} \mathrm{~W}_{n}$

Where:

$\mathrm{Z}_{\mathrm{i}}=$ Food security status $(1=$ Food secure, $0=$ Food insecure)

$\alpha$ and $\beta_{\mathrm{i}}$ are the parameters to be estimated.

$\mathrm{W}_{1}=$ age (Years)

$\mathrm{W}_{2}$ = years of formal education (Years)

$\mathrm{W}_{3}=$ household size (head count) 
four dimensional elements of food security as noted by OKUNEYE, 2002

\section{EFFECTS OF URBAN FOOD CROP FARMING ON HOUSEHOLDS' FOOD SECURITY STATUS}

Table 2: Food Security Status of the Respondents

\begin{tabular}{|c|c|}
\hline Variable & \\
\hline Cost of calorie equation & $\mathrm{LNH}=\mathrm{A}+\mathrm{BC}$ \\
\hline Intercept & $5.182031(104.11)$ \\
\hline Slope & $0.0001148(11.30)$ \\
\hline $\begin{array}{l}\text { FAO Recommended daily energy } \\
\text { requirement per adult equivalent }\end{array}$ & $2260 \mathrm{kcal} /$ day \\
\hline \multirow{4}{*}{$\begin{array}{l}\text { Recommended cost of minimum energy } \\
\text { requirement per adult equivalent }\end{array}$} & N230.78/day \\
\hline & $\mathrm{N} 1,615.46 /$ week \\
\hline & N6,923.40/month \\
\hline & $\mathrm{N} 84,234.70 /$ year \\
\hline Number of food secure respondents & 144 \\
\hline Number of food insecure respondents & 15 \\
\hline Percentage of food secure respondent & $90.57 \%$ \\
\hline Percentage of food insecure respondent & $9.43 \%$ \\
\hline
\end{tabular}

Source: Field Survey, (2017)

Table 3 revealed the result of the Probit regression model which was used to determine the effects of urban food crop farming on food security status of urban farm households in Oyo State, Nigeria. Out of 14 explanatory variables included in the model, 5 were found to significantly influence the probability of households to be food secure. These are age, household size, access to consumption credit, allocative efficiency and economic efficiency. Age of urban farm households significantly $(\mathrm{p}<0.05)$ affect food security. Being old tended to reduce the probability of food security of urban farm households by $0.05 \%$ while respondents' household size had the probability of reducing food security by $0.36 \%$. This is in line with previous findings by Ahmed and Abah, (2014); Babatunde et al., (2007a); (2007b).This result is consistent with theoretical a priori because the elderly are less productive and are unlikely to diversify their income source to be food secure; in addition, large household size will require greater calorie intake to consume and at greater cost of calorie otherwise they would most likely remain food insecure. Food security was discovered to be significantly $(p<0.05)$ affected by respondents' access to consumption credit. This implies that the probability of food security tend to increase with increase in access to consumption credit. This is in agreement with finding by Otunaiya and Ibridunni, (2014). Respondents' allocative efficiency was discovered to significantly $(\mathrm{p}<0.05)$ affect food security positively. The implication of this is that the probability of food security tended to increase with increase in the respondents' allocative efficiency. The respondents' economic efficiency significantly $(\mathrm{p}<0.05)$ affected their food security negatively. In other words, increase in the economic efficiency of urban farm households reduced the probability of their food security. By implication while the respondents were attempting to have the maximum ratio of their actual production total cost to expected production total cost at a given frontier of output, their probability of being food secure falls. This could be as a result of poor and inefficient allocation of production resources.

The results showed that the pseudo R2 was 0.3676 . This implies that $36.76 \%$ of the variation in food security status of the respondents is jointly explained by the 14 explanatory variables in the model. The log-likelihood of -31.4202 implies that the explanatory variables in the Probit regression model significantly explained the factors that had effect on food security of the urban farm households in the study area. Chisquare value of 36.52 associated with the log-likelihood was statistically significant $(\mathrm{p}<0.01)$ suggesting a strong explanatory power and goodness of fit of the model.

This research work recommends that consumption credit should be made available to urban food crop farmers timely as this facilitates their food security. This study further recommends that urban food crop farmers should be supported with inputs that promote greater output which enhances food security

Table 3: Probit Regression Estimate Showing the Effects of Urban Farming on Food Security

\begin{tabular}{|c|c|c|c|}
\hline variable & Coefficient & $\mathrm{Z}$ & $\begin{array}{c}\text { Marginal } \\
\text { effect }\end{array}$ \\
\hline Age & $-0.057573^{* *}$ & -2.34 & -0.000593 \\
\hline Education level & -0.042075 & -0.83 & -0.000434 \\
\hline Household size & $-0.351634^{* * *}$ & -3.26 & -0.003624 \\
\hline Farm size & 0.601644 & 1.32 & 0.006201 \\
\hline Urban farming experience & 0.020549 & 0.95 & 0.000212 \\
\hline Output of urban farming & 0.000022 & 0.13 & 0.0000002 \\
\hline Access to consumption credit & $1.713267^{* *}$ & 2.3 & 0.011159 \\
\hline Membership to farmers association & 0.144994 & 0.32 & 0.001432 \\
\hline Land ownership & 0.672808 & 1.33 & 0.009604 \\
\hline Proportion of consumed output & 1.193283 & 1.43 & 0.012299 \\
\hline Technical efficiency & 12.76854 & 1.27 & 0.131606 \\
\hline Allocative efficiency & $67.91355^{* *}$ & 2.08 & 0.699987 \\
\hline Economic efficiency & $-61.629500^{* *}$ & -2 & -0.635217 \\
\hline Income & 0.000004 & 0.92 & 0.0000 \\
\hline Constant & -15.3147 & -1.46 & \\
\hline Log-likelihood & -31.4202 & & \\
\hline Pseudo R2 & 0.3676 & & \\
\hline Prob $>$ chi 2 & 0.0009 & & \\
\hline LR chi2(14) & 36.52 & & \\
\hline Number of observations & 159 & & \\
\hline
\end{tabular}




\section{REFERENCES}

Adebayo, A.A. (2010). Food Security Status in Nigeria: Pre and Post Economic Deregulation Review, International Journal of Economic Development Research and Investment. 1(1):135-150

Adenegan, K.O. and Adewusi, O.A. (2007). Determinants of Food Security Status of Rural Households Living With HIV/AIDS in Southwestern Nigeria. African Journal of Biomedical Research. 10(1): 9-18

Adepoju, A.O., Adejare, K.A. (2013). Food Insecurity of Rural Households During Post-planting Season in Nigeria. Journal of Agriculture and Sustainability. 4(1):16-35

Adewuyi, S. A. (2002). Resource use productivity in food crop production in Kwara State, Nigeria. Unpublished PhD Thesis Submitted to the Department of Agricultural Economics, University of Ibadan, Nigeria pp. 109

Ahmed, F.F. and Abah, P.O. (2014). Determinants of Food Security among Low-income Households in Maiduguri Metropolis of Borno State, Nigeria. Asian Journal of Social Sciences and Humainities. 3(1):74-86

Asogwa, B.C. and Umeh, J.C. (2012). Food Insecurity Determinants among Rural Farm Households in Nigeria.Proceedings of International Conference on Ecology, Agriculture and Chemical Engineering (ICEACS), Phuket, Thailand pp. 206-211

Ayantoye, K., Yusuf, S.A., Omonoa, B.T. and Amao, J.O. (2011). Food Insecurity Dynamics and its Correlates among Rural Households in South-western Nigeria. International Journal of Agricultural Economics and Rural Development. 4(1):43-55

Babatunde, R.O., Omotesho, O.A. and Sholotan, O.S (2007a) Socio-economic Characteristics and Food Security Status of Farming Households in Kwara State, North-Central Nigeria. Pakistan Journal of Nutrition. 6(1):49-58

Babatunde, R.O., Omotesho, O.A. and Sholotan, O.S. (2007b) Factors Influencing Food Security Status of Rural Farming Households in North Central Nigeria. Agricultural Journal. 2(3):351-357

Famoriyo, O. A.(1998). Institutional Framework for Agriculture and Food Production in Nigeria: Future Prospects. Applied TropicalAgriculture. 3(1):1-9

Food and Agriculture Organisation of the United Nations (FAO) (2010). The State of Food Insecurity in the World (SOFI): Addressing Food Insecurity in Protracted Crises. Rome, Italy pp. 1-62 Goudie, A. (2002). Great Warm Deserts of the World: Landscape and Evolution. Oxford University Press New York pp. 5-12

Greer, J. andThorbecke, E. (1986). A Methodology for Measuring Food Poverty Applied to Kenya. Journal of Development Economics 24(1): 59-74

Gregory, P., Ingram, J.S.I., Brklacich, M. 2005. Climate Change and Food Security. Philosophical Transactions of the Royal Society B-Biological Sciences. 360 (1463):2139-2148

Ibrahim, H., Uba-Eze, N.R., Oyewole, S.O. and Onuk, E.G. (2009).Food Security among Urban Households: A Case Study of Gwagwalada Area Council of the Federal Capital Territory Abuja, Nigeria. Pakistan Journal of Nutrition.8(6):810-813

Jongwe, A. (2014). Synergies between Urban Agriculture and Urban Households Food Security in Gweru City, Zimbabwe. Journal of Development and Agricultural Economics. 6(2):59-66

Jrad, S., Nahas, B., Baghasa, H. 2010. Food Security Models. Ministry of Agriculture and Agrarian Reform, National Agricultural Policy Center. Syrian Arabic Republic. Policy Brief. 2(33):132

National Population Commission (NPC) (2006). Provisional Results, Abuja, Nigeria.

Nyasha Chaminuka and Ernest Dube (2017). Urban Agriculture as a Food Security Strategy for Urban Dwellers: A Case Study of Mkoba Residents in the City of Gweru, Zimbabwe International Journal of Social Science 3(2):26-45

Obayelu, A.E. (2012). Comparative Analysis of Household's Socioeconomic and Demographic Characteristics and Food Security Status in Urban and Rural Areas of Kwara and Kogi States of North-Central Nigeria, African Journal of Food, Agriculture Nutrition and Development. 12(3):6027-6054

Ogunniyi L.T., Fanifosi G.E. and Komolafe O.D. (2017).The Contribution of Urban Agriculture to Household Food Insecurity in Ibadan Metropolis, Oyo State, Nigeria. Scientia Agriculturae 17(2):42-47

Ojogho, O. (2010) Determinants of Food Insecurity among Arable Framers in Edo State, Nigeria. Agricultural Journal. 5(3):151-156. Okunneye, P.A.(2002). Rising Cost of Food Prices and Food Insecurity in Nigeria and Its Implication for Poverty Reduction. CBN Economicand Financial Review. 39 (4):6-11

Olagunju, F.I., Oke, J.T., Babatunde, R.O., Ajiboye, A. (2012). Determinants of Food Insecurity in Ogbomoso Metropolis of Oyo State, Nigeria. Journal of Production Agriculture and Technology. 8(1):111-124

Oluyole, K.A., Oni, O.A., Omonona, B.T. and Adenegan, K.O. (2009). Food Security among Cocoa Farming Households of Ondo State, Nigeria. ARPN Journal of Agriculture and Biological. Sciences. 4(1):7-13

Otunaiya, A.O. and Ibridunni, O.S. (2014). Determinants of Food Security among Rural Farming Households in Ogun State, Nigeria. Journal of Sustainable Development in Africa. 16(6):33-34

Rabinowicz, J. (2002). Urban Food Security and the Potential for Urban Agriculture. Accessed from http://www.g24.org/ukeje. pdf/2015 Accessed November 20, 2015

Sanusi, R.A., Badejo, C.A. and Yusuf, B.O. (2006). Measuring Household Food Insecurity in Selected Local Government Areas of Lagos and Ibadan, Nigeria. Pakistan Journal of Nutrition. 5(1):6267

Yusuf, S.A., Balogun, O.L. and Falegbe, O.E. (2015). Effect of Urban Household Farming on Food Security Status in Ibadan Metropolis, Oyo State Nigeria. Journal of Agricultural Sciences. 60(1):61-75 
